\title{
Effects of mesenchymal stem cells to prevent adhesions for vascular reoperations: An experimental study
}

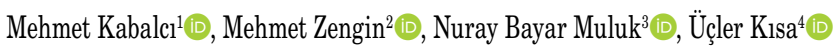 \\ ${ }^{1}$ Department of Cardiovascular Surgery, Medicine Faculty of Kirlkkale University, Krrlkkale, Turkey \\ ${ }^{2}$ Department of Pathology, Medicine Faculty of Kirlkkale University, Kirlkkale, Turkey \\ ${ }^{3}$ Department of Otorhinolaryngology Head and Neck Surgery, Medicine Faculty of Kirlkkale University, Kirlkkale, Turkey \\ ${ }^{4}$ Department of Biochemistry, Medicine Faculty of Kirlkkale University, Krrlkkale, Turkey
}

\begin{abstract}
Objectives: In the present study, we aimed to investigate whether mesenchymal stem cells (MSCs) were useful to reduce cutaneous adhesions, particularly for vascular reoperations.

Materials and methods: In this experimental study, 12 adult male Wistar Albino rats were used. In Group 1 ( $\mathrm{n}=2$, negative control group), no incision was performed. In Group 2 ( $n=5$, positive control group), skin and subcutaneous tissues were incised. In Group 3 ( $\mathrm{n}=5$, MSC group), skin and subcutaneous tissues were incised and 3×106 MSCs were applied. Macroscopic scoring of adhesion and histopathological scoring of tissue repair response were evaluated.

Results: Macroscopic view of the adhesion values ( $\left.\mathrm{P}_{\text {adjusted }}<0.0175\right)$, histopathological evaluation values (histiocytic response, vascularization, and granulocytic response and total response) ( $\left.\mathrm{P}_{\text {adjusted }}<0.0175\right)$, and collagen deposit values $\left(\mathrm{P}_{\text {adjusted }}<0.0175\right)$ of $\mathrm{Group}$ 3 were significantly lower than Group 2.

Conclusion: Our study results suggest that the use of MSCs seems to be useful to prevent adhesion formation in cutaneous injuries and that MSCs promote wound healing without adhesions in the experimental setting.

Keywords: Adhesions, cutaneous, mesenchymal stem cells, rat, vascular reoperations.
\end{abstract}

After abdominal surgeries, fibrosis, and adhesions may occur in more than $90 \%$ of patients, leading to bowel dysfunction, infertility, chronic pelvic discomfort, and difficult redo surgery. ${ }^{[1]}$

Postoperative adhesions are based on four main components: mesothelial cell loss, ${ }^{[2]}$ fibrin deposition, ${ }^{[3]}$ decreased fibrinolysis, ${ }^{[4]}$ and local inflammation. ${ }^{[5]}$ To reduce this adhesion, several methods have been used, such as to close only the regions over the large vessels, to use different synthetic and biological grafts, and to wash with dextran. ${ }^{[6]}$ Damaged tissue repair is completed in three stages. Tissue repair begins with hemostasis and, following the inflammatory period ending within 24 to 48 hours, proliferative and maturation stages occur. During the inflammatory period, the infection shield is strengthened by neutrophil and macrophage migration, and the foundations of tissue repair are discarded at this stage which can be considered as an identical with angiogenesis. ${ }^{[7]}$

Macrophages stimulate collagen production and angiogenesis by secretion of the transforming growth factor-beta (TGF- $\beta$ ), platelet-derived growth factor (PDGF), interleukin 1 (IL-1), platelet-activated factor (PAF), transforming growth factor alpha (TGF- $\alpha$ ), tumor necrosis factor alpha (TNF- $\alpha)$, fibroblast growth factor (FGF), and epidermal growth factor (EGF), in addition to fibroblastic proliferation and

Received: September 11,2019 Accepted: September 20, 2019 Published online: 0ctober 07, 2019

Correspondence: Mehmet Kabalıı, MD. Kırıkkale Üniversitesi Tıp Fakültesi Kalp ve Damar Cerrahisi Anabilim Dalı, 71450 Yahşihan, Kırıkkale, Turkey. e-mail: kabalci@hotmail.com 
differentiation. ${ }^{[8]}$ Following hemostasis, platelets and thrombus formation form the matrix tissue with the help of the cell transfer. ${ }^{[9]}$ Fibrinogen, fibronectin, platelet factor 4 (PF4), thromboxane A2 (TxA2), TGF- $\beta$, PDGF, amines, prostoglandines (PGs) that are discharged from platelet granules are the main components of angiogenesis and tissue repair. ${ }^{[10]}$

Mesenchymal stem cells (MSCs) can act as antiinflammatory, anti-proliferative, angiogenic, and immune modulator and inhibit the immune response in organ transplantations. ${ }^{[11]}$

In the present study, we aimed to investigated whether MSC were useful to reduce cutaneous adhesions, particularly for vascular reoperations in a rat model.

\section{MATERIALS AND METHODS}

This experimental study was carried out at Kirikkale University Animal Research Laboratory. The study protocol was approved by the Kirikkale University Animal Researches Local Ethics Committee (No. 17/48, Date: 01/12/2017). All animals received human care in compliance with the principles of laboratory animal care developed by the National Academy of Sciences.

\section{In Vivo rat model}

In this experimental study, a total of 12 healthy adult male Wistar Albino rats weighing 300 to $350 \mathrm{~g}$ and aged $>5$ months were used. In Group $1(n=2$, negative Control group), no incision was performed to the cutaneous and subcutaneous tissues. In Group 2 ( $n=5$, positive control group), skin and subcutaneous tissues were opened, contact of tissues with air and blood was maintained, and the skin was closed again after the contact. No further intervention was made. In Group 3 ( $n=5$, MSC group), skin and subcutaneous tissues were opened, contact of tissues with air and blood was maintained. Subsequently, $3 \times 10^{6} \mathrm{MSCs}$ were applied into the skin and subcutaneous tissues and the skin was closed.

Throughout the study, the animals were kept at the Animal Research Laboratory (Krrikkale University, Kirıkkale, Turkey) under veterinary supervision. The rats were kept at a room temperature of $25 \pm 1.9^{\circ} \mathrm{C}$ and humidity of $52 \pm 6 \%$, and received a standard diet as well as water ad libitum. All animals were followed for 24 days. On Day 24, all animals were euthanized, and blood and tissue samples were obtained for investigation.

\section{Isolation of MSCs}

Cell isolation and culture: The MSCs were isolated from the subcutaneous flank adipose tissue of rats using the method of Karaca et al. ${ }^{[12]}$

Cell characterization: The MSCs were characterized using immunofluorescence staining of CD13 and CD29 molecules using the method of Karaca et al. ${ }^{[12]}$ The flow cytometry analysis was performed against CD29, CD90, CD54, MHC Class I, CD45, CD106, and MHC Class II for characterization of MSCs. Flow cytometry analysis was performed. ${ }^{[13]}$

\section{Macroscopic scoring of the adbesions}

Adhesions in the cutaneous tissues were evaluated macroscopically as 0: No adhesions, 1: Slim and easily separable adhesions, 2: Moderate adhesions with blunt dissection, and 3: Severe adhesions necessitating sharp dissection.

\section{Histopathological scoring of tissue repair response}

In the study, samples were fixed in $4 \%$ formalin solution. After two days, tissue samples were washed with the water. Before embedding in the paraffin, tissue samples were soaked in ethanol $(60 \%, 70 \%$, $80 \%, 90 \%$, and $100 \%)$ and xylene for one hour. Cross sections were obtained and hematoxylin and eosin (H\&E) staining was used for the histopathological examinations. All samples were examined and classified semi-quantitatively between 0 and 3 in terms of fibrosis, histiocytic response, vascularization, and granulocytic response (Table 1). Using the Masson's trichrome staining (MTS), collagen deposits were evaluated as 0 to 3 (Table 1 ).

\section{The immunofluorescent antibody (IFA) imaging}

The green fluorescent protein (GFP)-labeled stem cells were visualized and recorded on a fluorescent antibody microscope.

\section{Caspase-3 measurements}

Caspase-3 levels of the blood samples were measured using an enzyme-linked immunosorbent assay (ELISA) kit (Elabscience, Wuhan, Hubei, China).

\section{Statistical analysis}

Statistical analysis was performed using the IBM SPSS version 20.0 (IBM Corp., Armonk, NY, USA). Descriptive data were expressed in median (min$\max$ ) or number and frequency. The Kruskal-Wallis analysis of variance and the Mann-Whitney $U$ test with the Bonferroni adjustment were performed. 
Table 1. Semi-quantitative classification for histopathological scoring

\begin{tabular}{lcccc}
\hline & \multicolumn{4}{c}{ Semiquantitative classification } \\
\cline { 2 - 5 } & 0 & 1 & 2 & 3 \\
\hline Fibrosis & $\mathrm{N}_{0}$ & Few fibroblasts & Fibroblastic proliferation and increased collagen & Fibrosis, collagen bundles \\
Histiocytic response & $\mathrm{N}_{0}$ & Rare macrophage & High amounts of histiocytes, rare multinucleated giant cells & Granuloma formation \\
Vascularization & No & Mild vasodilatation & Severe congestion & Hemorrhage + neovascularization \\
Granulocytic response & No & Low & Moderate & High \\
\hline
\end{tabular}

Table 2. Histopathological evaluation results of groups

\begin{tabular}{|c|c|c|c|c|c|c|c|}
\hline \multirow[b]{2}{*}{ Hematoxylin and eosin } & \multicolumn{2}{|c|}{$\begin{array}{c}\text { Group } 1 \\
\text { (Negative control) (n=2) }\end{array}$} & \multicolumn{2}{|c|}{$\begin{array}{c}\text { Group 2 } \\
\text { (Positive control) }(\mathrm{n}=5)\end{array}$} & \multicolumn{2}{|c|}{$\begin{array}{c}\text { Group } 3 \\
\text { (MSC group) (n=5) }\end{array}$} & \multirow[b]{2}{*}{$* p$} \\
\hline & Median & Min-Max & Median & Min-Max & Median & Min-Max & \\
\hline Fibrosis & 0 & $0-0$ & 2 & $2-3$ & 1 & $0-2$ & 0.024 \\
\hline Histiocytic response & 0 & $0-0$ & 3 & $3-3$ & 1 & $0-2$ & 0.008 \\
\hline Vascularization & 0 & $0-0$ & 2 & $2-3$ & 1 & $0-1$ & 0.009 \\
\hline Granulocytic response & 0 & $0-0$ & 3 & $2-3$ & 1 & $0-2$ & 0.013 \\
\hline Total response & 0 & $0-0$ & 10 & $9-11$ & 2 & $2-7$ & 0.008 \\
\hline \multicolumn{8}{|l|}{ Masson's trichrome } \\
\hline Collagen deposit & 0 & $0-0$ & 3 & $2-3$ & 1 & $0-2$ & 0.016 \\
\hline Macroscopic view of the adhesion & 0 & $0-0$ & 3 & $2-3$ & 0 & $0-2$ & 0.016 \\
\hline Caspase 3 pg/mL & 12.27 & $11.20-13.35$ & 12.25 & $11.58-13.67$ & 13.49 & $11.44-14.61$ & 0.573 \\
\hline
\end{tabular}

A $p$ value of $<0.05$ was considered statistically significant. When the Bonferroni adjustments were used, a $\mathrm{P}_{\text {adjusted }}$ value of $<0.0175$ was considered statistically significant.

\section{RESULTS}

According to the macroscopic examination, adhesion scores of Group 3 were significantly lower than Group 2 ( $\left.\mathrm{P}_{\text {adjusted }}<0.0175\right)$.
Histopathological evaluation results of all groups are shown on Table 1. Adhesions in the cutaneous tissues were evaluated macroscopically, and the difference among the groups was statistically significant $(\mathrm{p}<0.05)$ (Table 2). Pairwise comparisons which were performed to analyze the reason for the significant difference were performed (Table 3).

The fibrosis/adhesion severity and collagen deposit density were evaluated by H\&E and MST staining,

\begin{tabular}{|c|c|c|c|c|c|c|}
\hline \multirow[b]{2}{*}{ Hematoxylin and eosin } & \multicolumn{2}{|c|}{ Group 1-Group 2} & \multicolumn{2}{|c|}{ Group 1-Group 3} & \multicolumn{2}{|c|}{ Group 2-Group 3} \\
\hline & $\mathrm{z}$ & $P_{\text {adjusted }}$ & $\mathrm{z}$ & $P_{\text {adjusted }}$ & $\mathrm{z}$ & $\mathrm{P}_{\text {adjusted }}$ \\
\hline Fibrosis & -2.049 & 0.040 & -1.640 & 0.101 & -2.132 & 0.033 \\
\hline Histiocytic response & -2.449 & 0.014 & -1.296 & 0.195 & -2.805 & 0.005 \\
\hline Vascularization & -2.160 & 0.031 & -1.342 & 0.180 & -2.739 & 0.006 \\
\hline Granulocytic response & -2.049 & 0.040 & -1.673 & 0.094 & -2.495 & 0.013 \\
\hline Total response & -1.991 & 0.047 & -2.029 & 0.042 & -2.660 & 0.008 \\
\hline \multicolumn{7}{|l|}{ Masson's trichrome } \\
\hline Collagen deposit & -2.049 & 0.040 & -1.296 & 0.195 & -2.479 & 0.013 \\
\hline Macroscopic view & -2.049 & 0.040 & -0.966 & 0.334 & -2.495 & 0.013 \\
\hline
\end{tabular}


which were significantly increased in the positive control group, but not increased in the MSC group (Figure 1).

Using the H\&E staining, fibrosis, histiocytic response, vascularization, and granulocytic response and total response were analyzed and a statistically significant difference was observed $(p<0.05)$ (Table 3). Histiocytic response, vascularization, and granulocytic response and total response values of Group 3 were significantly lower than Group 2 ( $\left.\mathrm{P}_{\text {adjusted }}<0.0175\right)$.

Using the MTS, collagen deposit scores were evaluated and the difference among groups was statistically significant $(\mathrm{p}<0.05)$ (Table 2). Pairwise comparison results are presented in Table 3. Collagen deposit scores of Group 3 (MSC group) were significantly lower than Group $2\left(\mathrm{P}_{\text {adjusted }}<0.0175\right)$.

\section{DISCUSSION}

In case of insufficient or excessive healing processes, a non-healing wound or a hypertrophic scar, including functional loss may occur. It may also cause psychosocial effects. ${ }^{[14]}$ The stages of the physiological wound healing is hemostasis, inflammation, proliferation, and remodeling. ${ }^{[15,16]}$ During the proliferative phase, there are formation of granulation tissue, deposition of the collagen, reepithelization and wound contraction. If there is no full regeneration, repair damage occurs, such as scar formation. ${ }^{[14,17-19]}$

Several different cell types including macrophages, fibroblasts, and contractile myofibroblasts participate in the proliferative phase of wound repair and play a critical role in regulating the size and quality of the scar. ${ }^{[17-19]}$

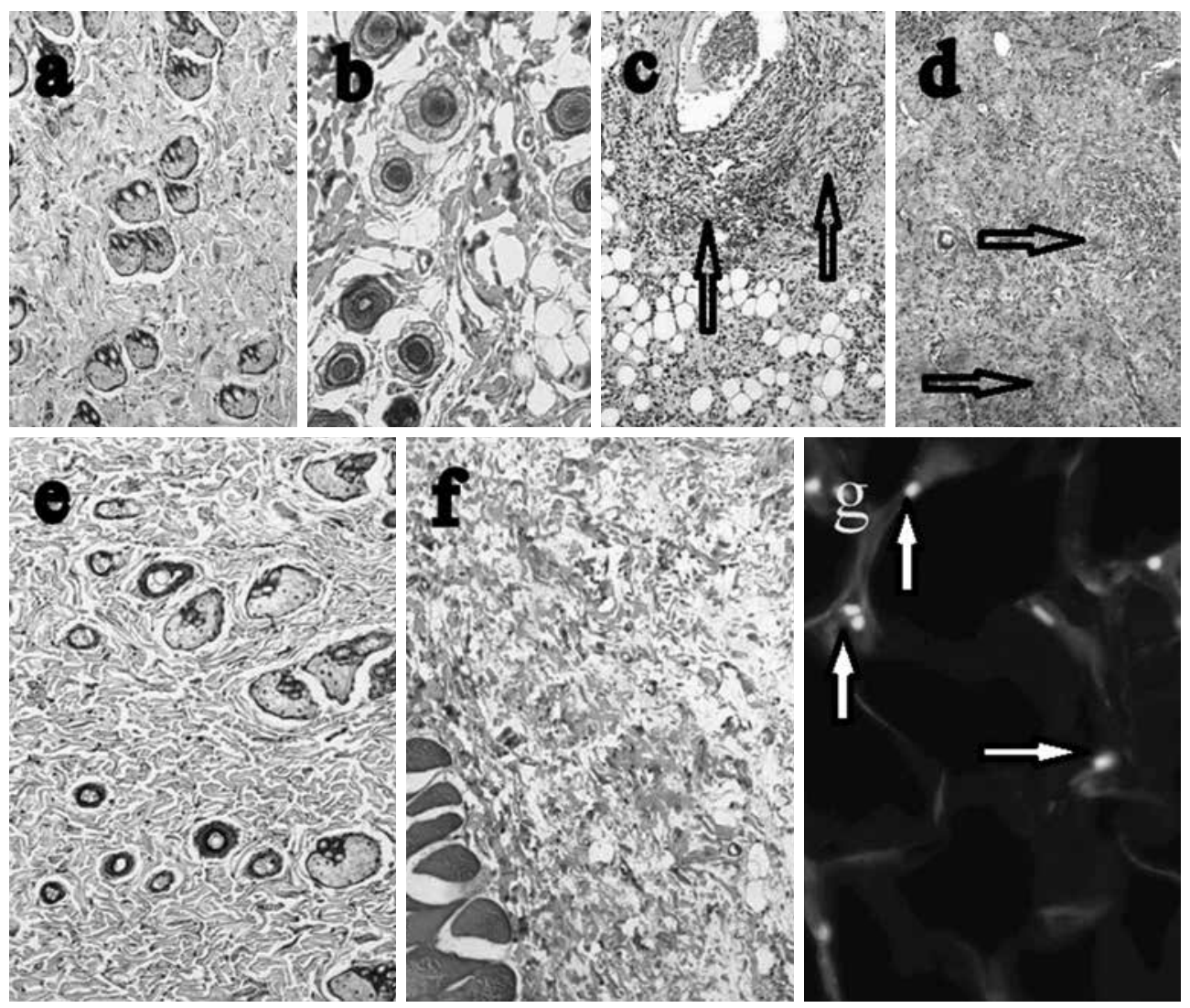

Figure 1. Representative examples of negative control cases (Group 1), non-stem cell cases (Group 2), and stem cell cases (Group 3). The stem cell evaluation was visually estimated by a single pathologist on H\&E, MTS, and immunofluorescence stain sections in a semi-quantitative manner. Slides were scanned at $\times 20$ magnification $\left(0.785 \mathrm{~mm}^{2}\right)$. Area representing negative control cases (Group 1) showing no inflammation (a, b), positive control cases (Group 2) (c, d) showing intense inflammation (arrows), and stem cell cases (Group 3) (d-f) showing minimal inflammation with immunofluorescent positive stem cells (Group 3) (g) (arrows) were observed.

H-E: Hematoxylin and eosin; MTS: Masson's trichrome staining. 
The TGF- $\beta$ is released by macrophages in the wound, and the ability of these cells to migrate and adhere to granulation tissue is responsible for the presence of TGF- $\beta$ during recovery. The TGF- $\beta$ and other cytokines cause the filling of the wound by mesenchymal cells. ${ }^{[19]}$ There is macrophage cell plasticity and these cells can produce different phenotype of fibroblast-like cells. Migration in other cell types is associated with the ability to obtain mesenchymal phenotype. ${ }^{[18,20-22]}$

In the present study, we investigated the efficacy of MSCs to prevent cutaneous adhesions in a rat model for vascular reoperations. Macroscopic view of the adhesion scores, histopathological evaluation scores (histiocytic response, vascularization, and granulocytic response and total response), and collagen deposit scores of Group 3 were significantly lower than Group 2. Our results showed that the use of MSCs helped to prevent adhesion formation in cutaneous injuries.

Adult MSCs can differentiate into various cells and tissues, showing a critical role in wound repair and tissue regeneration. Due to their multipotency and immunosuppressive abilities, they are an attractive treatment tool for regenerative medicine and tissue engineering. ${ }^{[23]}$ The MSCs also contribute to the reconstruction of the skin in cutaneous wounds; however, there are still difficulties to overcome, before MSCs are widely used in the clinical setting. ${ }^{[24]}$

Cardiovascular adherences may cause an increased risk for inadvertent damages in the heart and large vessels and intraoperative bleeding. ${ }^{[25]}$ Medical or biomedical options to limit and control perivascular adherences have to incorporate the recent advancements of pathogenesis and pathophysiology of adhesions. ${ }^{[26]}$ Transplanted MSCs may differentiate into various cell lines in wound areas and provide immunomodulatory effects. ${ }^{[23]}$ The MSCs can support in vivo wound healing by varying to the endothelial cells, myofibroblasts, and pericytes. ${ }^{[27]}$

The induction of mechanical stress in the skin leads to the release of chemokines which are involved in various cytokines, particularly those recruit MSCs in the bloodstream. ${ }^{[28]}$ In addition, these chemokines increase the bone marrow stem cell mobility, thereby facilitating mobilization of MSCs into the peripheral blood and wound healing sites. The accumulation of MSCs in injured areas may transdifferentiate more than one skin component cell type and, thus, contribute to wound repair. ${ }^{[27]}$
Physiological accumulation of sufficient MSCs can lead to more cell type differentiation. The result is better functional organization of injured tissue. The accumulation of circulating MSCs, usually given from the bone marrow stroma to specific tissue, may be one of the effective strategies for tissue regeneration. ${ }^{[27]}$

In clinical trials, MSCs have been used for the successful treatment of chronic wounds and have been reported in skin wound healing, including the inflammatory, proliferation and remodeling phases. The MSC treatment via intradermal injection have been shown to significantly accelerate the wound closure. ${ }^{[29-32]}$

The preclinical design in an animal model is the main limitation of the present study. Therefore, the true effect of MSCs should be investigated in further studies in human.

In conclusion, our study results suggest that the use of MSCs seems to be useful to prevent adhesion formation in cutaneous injuries and that promote wound healing without adhesions in the experimental setting. However, the use of MSCs to prevent adhesions in humans must be further investigated, particularly in revision cases.

\section{Declaration of conflicting interests}

The authors declared no conflicts of interest with respect to the authorship and/or publication of this article.

\section{Funding}

The authors received no financial support for the research and/or authorship of this article.

\section{REFERENCES}

1. Liakakos T, Thomakos N, Fine PM, Dervenis C, Young RL. Peritoneal adhesions: etiology, pathophysiology, and clinical significance. Recent advances in prevention and management. Dig Surg 2001;18:260-73.

2. Roselli EE, Pettersson GB, Blackstone EH, Brizzio ME, Houghtaling PL, Hauck R, et al. Adverse events during reoperative cardiac surgery: frequency, characterization, and rescue. J Thorac Cardiovasc Surg 2008;135:316-23.

3. Park CB, Suri RM, Burkhart HM, Greason KL, Dearani JA, Schaff HV, et al. Identifying patients at particular risk of injury during repeat sternotomy: analysis of 2555 cardiac reoperations. J Thorac Cardiovasc Surg 2010;140:1028-35.

4. Shahian DM, O'Brien SM, Filardo G, Ferraris VA, Haan CK, Rich JB, et al. The Society of Thoracic Surgeons 2008 cardiac surgery risk models: part 1--coronary artery bypass grafting surgery. Ann Thorac Surg 2009;88:2-22. 
5. Sabik JF 3rd, Blackstone EH, Gillinov AM, Banbury MK, Smedira NG, Lytle BW. Influence of patient characteristics and arterial grafts on freedom from coronary reoperation. J Thorac Cardiovasc Surg 2006;131:90-8.

6. Zapolanski A, Fishman NH, Bronstein MN, Ellertson DG, O'Connell TJ, Siegel S. Modified pericardial closure to protect cardiovascular structures during sternal reentry. Ann Thorac Surg 1990;50:665-6.

7. Sayek İ, Ozmen MM. Temel Cerrahi El Kitabı. Ankara: Güneş Tıp Kitabevleri: 2009.

8. Brunicardi CF. Schwartz's Principles of Surgery. New York: Mc Graw-Hill; 2005.

9. Ergin DN. Farklı Dikiş Materyallerinin Gingivada Oluşturduğu Doku Reaksiyonunun Değerlendirilmesi (Doktora Tezi). Ankara: Başkent Univeritesi; 2009).

10. Jeffcoate WJ, Price P, Harding KG; International Working Group on Wound Healing and Treatments for People with Diabetic Foot Ulcers. Wound healing and treatments for people with diabetic foot ulcers. Diabetes Metab Res Rev 2004;20:78-89.

11. Li J, Ezzelarab MB, Cooper DK. Do mesenchymal stem cells function across species barriers? Relevance for xenotransplantation. Xenotransplantation 2012;19:273-85.

12. Karaca G, Pehlivanli F, Aydin O, Altunkaya C, Uzun H, Niyaz M, et al. The effect of mesenchymal stem cell use on intra-abdominal adhesions in a rat model. Ann Surg Treat Res 2018;94:57-62.

13. Niyaz M, Gurpınar OA, Gunaydın S, Fu SC, Lee YW, Chan KM. Isolation, culturing and characterization of rat adipose tissuederived mesenchymal stem cells: a simple technique. Turk J Biol 2012;36:658-64

14. Amini-Nik S, Cambridge E, Yu W, Guo A, Whetstone $\mathrm{H}$, Nadesan P, et al. Beta-Catenin-regulated myeloid cell adhesion and migration determine wound healing. J Clin Invest 2014;124:2599-610.

15. Gurtner GC, Werner S, Barrandon Y, Longaker MT. Wound repair and regeneration. Nature 2008;453:314-21.

16. Bielefeld KA, Amini-Nik S, Alman BA. Cutaneous wound healing: recruiting developmental pathways for regeneration. Cell Mol Life Sci 2013;70:2059-81.

17. Hinz B, Phan SH, Thannickal VJ, Prunotto M, Desmoulière $\mathrm{A}$, Varga $\mathrm{J}$, et al. Recent developments in myofibroblast biology: paradigms for connective tissue remodeling. Am J Pathol 2012;180:1340-55.

18. Radisky DC, Kenny PA, Bissell MJ. Fibrosis and cancer: do myofibroblasts come also from epithelial cells via EMT? J Cell Biochem 2007;101:830-9.

19. DiPietro LA, Burdick M, Low QE, Kunkel SL, Strieter RM. MIP-1alpha as a critical macrophage chemoattractant in murine wound repair. J Clin Invest 1998;101:1693-8.
20. Peters T, Sindrilaru A, Hinz B, Hinrichs R, Menke A, Al-Azzeh EA, et al. Wound-healing defect of CD18(-/-) mice due to a decrease in TGF-beta1 and myofibroblast differentiation. EMBO J 2005;24:3400-10.

21. Cai J, Guan H, Fang L, Yang Y, Zhu X, Yuan J, et al. MicroRNA-374a activates $\mathrm{Wnt} / \beta$-catenin signaling to promote breast cancer metastasis. J Clin Invest 2013;123:566-79.

22. Chaffer CL, Weinberg RA. A perspective on cancer cell metastasis. Science 2011;331:1559-64.

23. Wang W, Li P, Li W, Jiang J, Cui Y, Li S, et al. Osteopontin activates mesenchymal stem cells to repair skin wound. PLoS One 2017;12:e0185346.

24. Fu X1, Li H. Mesenchymal stem cells and skin wound repair and regeneration: possibilities and questions. Cell Tissue Res 2009;335:317-21.

25. Cannata A, Petrella D, Russo CF, Bruschi G, Fratto $\mathrm{P}$, Gambacorta $\mathrm{M}$, et al. Postsurgical intrapericardial adhesions: mechanisms of formation and prevention. Ann Thorac Surg 2013;95:1818-26.

26. Rocca A, Aprea G, Surfaro G, Amato M, Giuliani A, Paccone $M$, et al. Prevention and treatment of peritoneal adhesions in patients affected by vascular diseases following surgery: a review of the literature. Open Med (Wars) 2016;11:106-14.

27. Sasaki M, Abe R, Fujita Y, Ando S, Inokuma D, Shimizu H. Mesenchymal stem cells are recruited into wounded skin and contribute to wound repair by transdifferentiation into multiple skin cell type. J Immunol 2008;180:2581-7.

28. Rochefort GY, Delorme B, Lopez A, Hérault O, Bonnet P, Charbord $\mathrm{P}$, et al. Multipotential mesenchymal stem cells are mobilized into peripheral blood by hypoxia. Stem Cells 2006;24:2202-8.

29. Mazzini L, Mareschi K, Ferrero I, Vassallo E, Oliveri G, Boccaletti R, et al. Autologous mesenchymal stem cells: clinical applications in amyotrophic lateral sclerosis. Neurol Res 2006;28:523-6.

30. Moviglia GA, Fernandez Viña R, Brizuela JA, Saslavsky J, Vrsalovic F, Varela G, et al. Combined protocol of cell therapy for chronic spinal cord injury. Report on the electrical and functional recovery of two patients. Cytotherapy 2006;8:202-9.

31. Paquet-Fifield S, Schlüter H, Li A, Aitken T, Gangatirkar P, Blashki D, et al. A role for pericytes as microenvironmental regulators of human skin tissue regeneration. J Clin Invest 2009;119:2795-806.

32. Maxson S, Lopez EA, Yoo D, Danilkovitch-Miagkova A, Leroux MA. Concise review: role of mesenchymal stem cells in wound repair. Stem Cells Transl Med 2012;1:142-9. 